\title{
Профі.лактика та лікування реперфузійного пошкодження тканин при реконструкції артеріального русла аорто-стегно-підколінного сегмента в умовах хронічної критичної ішемії
}

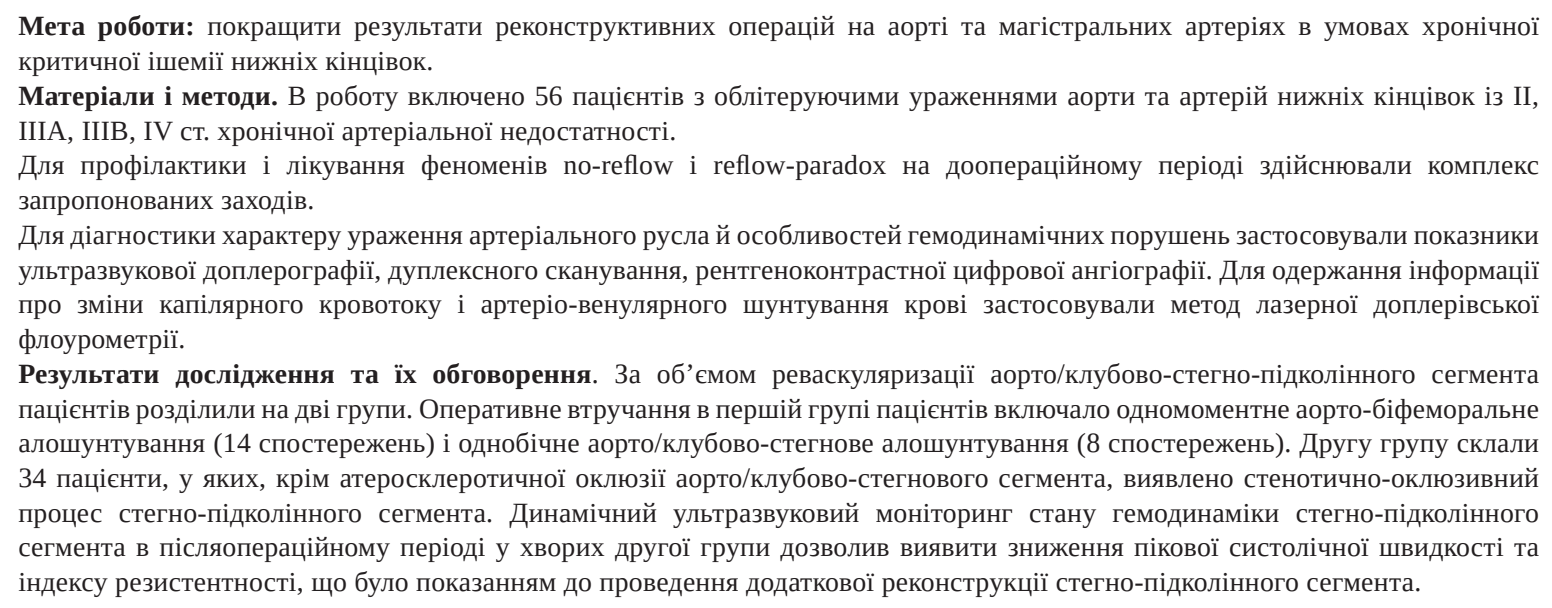

Ключові слова: облітеруючий атеросклероз; реперфузійно-реоксигенаційний синдром; реваскуляризація.

Постановка проблеми і аналіз останніх досліджень та публікацій. Оклюзійно-стенотичні ураження артерій нижніх кінцівок складають близько 20 \% всіх проявів патології системи кровообігу [1]. Незважаючи на застосування новітніх лікарських засобів, основним етапом комплексного лікування хронічної артеріальної недостатності нижніх кінцівок залишаються реконструктивні втручання [2]. Післяопераційні ускладнення при реваскуляризуючих втручаннях на аорті та магістральних артеріях нижніх кінцівок знаходяться на рівні 2,7 - 3,2 \% [3]. Однією з причин несприятливих наслідків реконструкції аорто-стегно-підколінного сегмента $є$ розвиток реперфузійно-реоксигенаційного синдрому [4].

Пусковим фактором у розвитку реперфузійно-реоксигенаційного синдрому нижніх кінцівок $\epsilon$ надходження кисню в ішемізовані тканини. Клітини ішемізованих тканин інтенсивно поглинають кисень, що супроводжується утворенням значної кількості перекисних сполук, яким не можуть протидіяти антиоксидантні системи. Одночасно активація перикисного окислення ліпідів супроводжується пошкодженням клітинних мембран [5] і вільнорадикальним некробіозом [6, 7]. Розви- ток феномену no-reflow пов'язаний із порушенням прохідності мікроциркуляторного русла, що призводить до недостатності капілярної перфузії. Остання розвивається як наслідок часткової лейкоцитарної оклюзії венозного сегмента мікроциркуляторного русла, адгезії лейкоцитів до ендотелію капілярів; утворення реактивних метаболітів кисню і звільнення агресивних медіаторів із наступною втратою ендотеліальної цілісності і наростання капілярної проникності і внутрішньотканинного набряку (reflow-paradox) [8]. Вже розвинутий реперфузійно-реоксигенаційний синдром пролонгує ішемію тканин нижньої кінцівки, що сприяє прогресуванню в них процесів дистрофії і спрямовує генералізований депресивний вплив на органи і системи.

Ефективність комплексного лікування можна досягнути при застосуванні методів та способів у складі реконструктивного втручання, що уповільнюють надходження кров'яного потоку під час реваскуляризації нижньої кінцівки.

Мета роботи: покращити результати реконструктивних операцій на аорті та магістральних артеріях в умовах хронічної критичної ішемії нижніх кінцівок. 
Матеріали і методи. В роботу залучено 56 пацієнтів. 3 них у 39 діагностовано різні варіанти атеросклеротичної оклюзії аорто-стегнового сегмента, з яких у 25 виявлено стенотично-оклюзивний процес стегно-підколінного сегмента нижньої кінцівки. У 17 встановлено атеросклеротичну оклюзію клубового сегмента, з яких у 9 - стенотично-оклюзивний процес стегно-підколінного сегмента.

У всіх пацієнтів нижня кінцівка із високим ризиком розвитку реперфузійно-реоксигенаційних ускладнень характеризувалась IIIA-B-IV ст. ХАН, контрлатеральна нижня кінцівка - ІІст. ХАН (за класифікацією Fontaine R. з врахуванням критеріїв Європейської робочої групи (1992).

Для профілактики і лікування феноменів поreflow i reflow-paradox на доопераційному періоді здійснювали: ліквідацію вазоконстрикції шляхом проведення пролонгованої епідуральної анестезії та інфузію вазопростану (алпростану, вазостенону); зниження нейтрофільної активності та рівня системної запальної відповіді за допомогою проведення одного-двох сеансів лейкаферезу; підвищення опірності ендотелію шляхом призначення бетаблокатора (невибол), престаріуму та L-аргеніну; нормалізацію мікросудинної проникності здійснювали призначенням сольового гіперосмотичного гіпертонічного декстрану; підвищення активності прооксидантно-антиоксидантної рівноваги досягали призначенням альфа-токоферолу та внутрішньовенним введенням Корвітину. Для досягнення антиішемічного ефекту призначали внутрішньовенне введення Рефортану.

Для діагностики характеру ураження артеріального русла й особливостей гемодинамічних порушень застосовували показники ультразвукової доплерографії, дуплексного сканування, рентгеноконтрастної цифрової ангіографії.

Для одержання інформації про зміни капілярного кровотоку і артеріо-венулярного шунтування крові застосовували метод лазерної доплерівської флоурометрії (ЛДФ), використовуючи апарат ЛАКК (“ЛАЗМА”, Росія). Дослідження проводили в ділянці основи великого пальця стопи.

Визначали базальний рівень перфузії тканин (ПШ), концентрацію еритроцитів (KЕ). Рівень перфузії тканин залежить від концентрації еритроцитів і швидкості їх пересування, швидкість капілярного кровотоку (ШКК) розраховували шляхом ділення рівня ПШ на показник КЕ. Шкірний перфузійний тиск (ШПТ) визначали за допомогою методу лазерної доплерівської флоурометрії із використанням сфігмоманометричного методу. Для оцінки результатів проводили визначення відно- шення ШПТ/РСТ (регіонарний систолічний тиск) - індекс шкірного тиску (ІШТ). Індекс опору мікроциркуляторного русла (IОМР) розраховували за формулою Хагена-Пуазеля як відношення величини перфузійного тиску до інтегральної величини перфузії шкіри.

\section{Результати досліджень та їх обговорення.} Після 5 - 8 доби підготовки реваскуляризацію розпочинали із катетиризації загальної стегнової артерії нижньої кінцівки із IIIA-B-IV, через яку внутрішньоартеріально протягом часу проведення доступу та маніпуляцій на аорто/клубовому сегменті вводили 100 мл 0,03 \% розчину гіпохлориту натрію і 0,5 г. Корвітину у 100 мл фізіологічного розчину.

При аорто-біфеморальному алошунтуванні відновлювали кровотік по браншах алошунта почергово: спершу по бранші непроблемної нижньої кінцівки, потім по бранші нижньої кінцівки, яка може спровокувати розвиток реперфузійно-реоксигенаційних ускладнень. Вказана послідовність відновлення кровотоку по браншах алопротеза дає змогу вдвічі знизити силу ударної хвилі кровотоку в артеріальному руслі проблемної нижньої кінцівки.

У 7 пацієнтів із однобічною оклюзією клубово-стегнового сегмента і високим ризиком розвитку реперфузійно-реоксигенаційних ускладнень діагностовано стенотичний атеросклеротичний процес (63-81 \%) контрлатерального клубового сегмента. У вказаних умовах пікова систолічна швидкість (ПСШ) на загальній клубовій артерії досягало 180 - 200 см/с. Вказані обставини вимагають проведення біфуркаційного аорто-стегнового алошунтування. Формуючи аорто-біфеморальний алошунт, дотримувались почергового відновлення кровотоку по браншах алопротеза - в другу чергу відновлення кровотоку по бранші нижньої кінцівки, яка могла б спровокувати розвиток реперфузійно-реоксигенаційних ускладнень, і попереджували розвиток тромбозу артеріального русла контрлатеральної нижньої кінцівки (Патент України на корисну модель № 115930) у разі формування тільки однобічного аорто(клубово)стегнового алошунта.

За об’ємом оперативної реваскуляризації аорто/клубово-стегно-підколінного сегмента пацієнтів розділили на дві групи. Оперативне втручання в пацієнтів першої групи включало одномоментне аорто-біфеморальне алошунтування (14 спостережень) і однобічне аорто/клубово-стегнове алошунтування (8 спостережень). В другу групу становили 34 пацієнти, у яких, крім атеросклеротичної оклюзії аорто/клубово-стегнового сег- 
мента, виявлено стенотично-оклюзивний процес стегно-підколінного сегмента. Із них 25 хворим на першому етапі проведено тільки аорто-біфеморальне алошунтування і 9 - тільки однобічне аорто(клубово)-стегнове алошунтування.

У 21 пацієнта другої групи на третю добу раннього післяопераційного періоду при проведенні УЗД встановили, що ПСШ і IP на рівні глибокої артерії стегна (ГАС) досягають меж, відповідно, 23,2 - 1,5 cм/с і 0,41 - 0,29 у.о., а ПСШ і IP на рівні тібіоперинеального стовбура (ТПС) знаходяться, відповідно, в межах 17,1-3,1 см/с і 0,39 - 0,11 у.о. (табл. 1). Отримані результати визначення ПСШ i IP на ГАС та ТПС нижчі, відповідно, у 1,9 (p < 0,05) i 1,5 (p < 0,05) раза за показники, що були на першу добу раннього післяопераційного періоду і вказують на прогресуюче погіршення кровопостачання дистальних відділів нижньої кінцівки. Подібне відбувається за рахунок блокування оклюзивним процесом стегно-підколінного сегмента анастомозів ГАС із низхідною артерією коліна та підколінною артерією. Наведена ситуація була показанням до проведення стегно-дистальної реконструкції. I на третю добу післяопераційного періоду проведено стегно-дистальне автовенозне шунтування (16 спостережень), а в 5 спостереженнях здійснено ротаційно-аспіраційну атероектомію із дистального сегмента поверхневої артерії стегна.

Відстрочена реваскуляризація стегно-дистального артеріального русла має позитивний характер, окрім відновлення повноцінного кровопостачання дистальних відділів нижньої кінцівки, запобігає раптовому кисневому удару периферії артеріального русла. Це можна прослідкувати, досліджуючи через 48 год після оперативного втручання стан мікроциркуляторного русла у трьох групах оперованих пацієнтів: I група (20 пацієнтів) із одномоментним аорто-біфеморальним алошунтуванням (13 спостережень) і однобічним аорто/клубово-стегновим алошунтуванням (7 спостереження); II група (13 пацієнтів) тільки із аорто-біфеморальним алошунтуванням при стегнодистальній оклюзії; 3 група (21 пацієнт) із аортобіфеморальним алошунтуванням і відстроченою стегно-дистальною реконструкцією артеріального русла нижньої кінцівки.

Таблиця 1. Ультразвукові показники артеріальної гемодинаміки

\begin{tabular}{|c|c|c|c|c||}
\hline \multirow{2}{*}{} & \multicolumn{2}{|c|}{ ПСШ, см/с } & \multicolumn{2}{c||}{ ІР, у.о. } \\
\cline { 2 - 5 } & ГАС & ТПС & ГАС & $0,82 \pm 0,03$ \\
\hline Норма & $52,6 \pm 11,3$ & $45,5 \pm 7,3$ & $0,89 \pm 0,05$ & $0,50 \pm 0,08$ \\
\hline І доба п/о & $43,7 \pm 6,1$ & $32,9 \pm 2,8$ & $0,58 \pm 0,09$ & $0,34 \pm 0,11$ \\
\hline ІІІ доба п/о & $23,2 \pm 1,5$ & $17,1 \pm 3,1$ & $0,38 \pm 0,11$ & ТП \\
\hline
\end{tabular}

При аналізі результатів дослідження стану мікроциркуляторного русла через 48 год після реваскуляризації нижніх кінцівок встановлено суттєве покращення його функціональної здатності (табл. 2). Поряд з цим, встановлено різницю в рівні функціонального стану мікроциркуляторного русла після застосування різних типів та об'єму реваскуляризуючих оперативних втручань. Так, при виконанні через 72 год після проведення аорто/клубово-стегнового шунтування відстроченої реваскуляризації дистальних відділів нижньої кінцівки встановлено найкращі показники функціонального стану мікроциркуляторного русла. У вказаній групі пацієнтів рівень ПШ, КЕ, ШКК був вищим, відповідно, у 1,5 (р < 0,05), 1,4 (р < 0,05) i 1,2 раза за показники у доопераційному періоді. Наведене відбувалось за рахунок зниження шкірного перфузійного тиску (ШПТ), індексу опору мікроциркуляторного русла (IOMP), що в кінцевому результатів сприяло досягненню тканинної оксигенації на рівні $(5,04 \pm 0,37)$ мм рт.ст.

Аналіз результатів реконструктивних операцій підтвердив, що застосовуючи патофізіологіч- но обгрунтовану передопераційну підготовку та хірургічні прийоми в складі реваскуляризуючих оперативних втручань вдалось запобігти розвитку таких ускладнень, як поглиблення ішемії нижньої кінцівки, вираженої ниркової недостатності та деяких інших грізних реперфузійних ускладнень. Це досягнуто завдяки комплексному підходу до профілактики реперфузійно-реоксигенаційного синдрому шляхом застосування у передопераційному періоді ліквідації вазоконстрикції, зниження нейтрофільної активності, нормалізації стану ендотелію, підвищення мікросудинної проникності, відновлення прооксидантно-антиоксидантної рівноваги. Важливе значення відіграли способи, оперативні втручання, що входять у реваскуляризуючу операцію, головною ціллю яких було зниження сили ударної хвилі кровотоку.

Поряд 3 цим, на інтраопераційному етапі та в ранньому післяопераційному періоді діагностували ряд ускладнень, ініційованих реперфузійнореоксигенаційним синдромом. Серед них було 6 $(10,71 \%)$ випадків порушення ритму і провідності серцевого м'яза, один (1,79 \%) інтерстиціальний 
Таблиця 2. Стан мікроциркуляторного русла та тканинної оксигенації у пацієнтів із ризиком розвитку реперфузійно-реоксигенаційних ускладнень

\begin{tabular}{||l|c|c|c|c||}
\hline \hline Показники & До операції & $\begin{array}{c}\text { Аорто(клубово)- } \\
\text { біфеморальне } \\
\text { алошунтування за } \\
\text { відсутності оклюзії } \\
\text { стегно-підколінного } \\
\text { сегмента }\end{array}$ & $\begin{array}{c}\text { Аорто(клубово)- } \\
\text { біфеморальне } \\
\text { алошунтування } \\
\text { при оклюзії стегно- } \\
\text { підколінного } \\
\text { сегмента }\end{array}$ & $\begin{array}{c}\text { Аорто(клубово)- } \\
\text { біфеморальне } \\
\text { алошунтування, } \\
\text { відстрочена } \\
\text { реконструкція стегно- } \\
\text { підколінного сегмента }\end{array}$ \\
\hline ПШ, ПЕ & $24,32 \pm 4,25$ & $28,71 \pm 4,65$ & $34,76 \pm 4,49 *$ & $38,48 \pm 4,45^{*}$ \\
\hline КЕ, ум.од. & $18,86 \pm 5,31$ & $22,61 \pm 5,72$ & $23,34 \pm 5,44$ & $26,63 \pm 5,74$ \\
\hline ШКК, см/с & $1,20 \pm 0,07$ & $1,23 \pm 0,07$ & $1,36 \pm 0,09 *$ & $1,45 \pm 0,13^{*}$ \\
\hline ШПТ, мм.рт.ст. & $34,41 \pm 4,31$ & $32,99 \pm 4,31$ & $30,27 \pm 4,41$ & $29,69 \pm 4,51$ \\
\hline ІШТ, ум.од. & $1,28 \pm 0,17$ & $1,28 \pm 0,17$ & $1,19 \pm 0,10$ & $1,18 \pm 0,09$ \\
\hline IОМР & $1,51 \pm 0,09$ & $1,42 \pm 0,09$ & $1,32 \pm 0,07 *$ & $1,29 \pm 0,10^{*}$ \\
\hline Тс рО2, мм.рт.ст. & $2,75 \pm 0,19$ & $3,58 \pm 0,19 *$ & $4,09 \pm 0,23^{*}$ & $5,04 \pm 0,27 *$ \\
\hline \hline
\end{tabular}

* - достовірна різниця між показниками до операції та показниками після реваскуляризації нижніх кінцівок.

набряк легень та 4 (7,14 \%) прояви минущої ниркової недостатності.

Потрібно зазаначити, що 7 (31,81 \%) випадків ускладнень виявлено в пацієнтів (22 спостережень), у яких не було діагностовано стенотично-оклюзивного процесу стегно-підколінного сегмента і їм виконано тільки аорто/клубово-стегнове алошунтування. Пацієнтам (13 спостережень), у яких діагностовано стенотично-оклюзивний процес стегно-дистального сегмента, виконано тільки аорто/клубово-біфеморальне алошунтування, виявлено 3 (23,1 \%) випадки ускладнень, ініційованих реперфузійним синдромом. У пацієнтів (21 спостереження), яким проведено відстрочену реконструкцію стегно-дистального артеріального

\section{СПИСОК ЛІТЕРАТУРИ}

1. Заболевания периферических артерий / Э. Р. Молер, М. Р. Джафф ; пер. с англ. М. В. Писарев. - Москва : ГЭОТАРМедиа, 2010. - 224 с.

2. Белов Ю. В. Повторные реконструктивные операции на аорте и магистральных артериях / Ю. В. Белов, А. Б. Степаненко. - Москва : МИА, 2009. - 176 с.

3. Особенности хирургической тактики при многоуровневых окклюзионно-стенотических поражениях бедренноберцового артериальных сегментов / П. И. Никульников, А. Н. Быцай, А. В. Ратушнюк, А. В. Ликсунов // Харківська хірургічна школа. - 2013. - № 3. - С. 148-151.

4. Маршалов Д. В. Реперфузионный синдром - понятие, опредиление, классификация / Д. В. Маршалов, А. П. Петренко, И. А. Глушач // Патология кровообращения и кардиохирургия. - 2008. - № 3. - С. 67-72.

5. Basic control of reperfusion effectively protects against reperfusion injury in a realistic rodent model of acute limb русла, діагностували одне (4,75 \%) ускладнення у вигляді минущої ниркової недостатності саме після проведення основного хірургічного втручання - аорто/клубово-біфеморальне алошунтування.

Висновки. Застосування патофізіологічно обгрунтованої профілактики та лікування реперфузійно-реоксигенаційного синдрому, яка включає вплив та корекцію основних ланок механізму формування реперфузійного синдрому, використання методів у складі реваскуляризуючого оперативного втручання, які знижують силу ударної хвилі кровотоку в артеріальному руслі, дало змогу запобігти розвитку грізних реперфузійних ускладнень.

ischemia / F. Dick, J. Li, V. N. Girarud [et al.] // Circulation. 2008. - Vol. 118 (19). - P. 1920-1928.

6. Костів С. Я. Корекція реперфузійного синдрому при хірургічному лікуванні пацієнтів із атеросклеротичною оклюзією аорто-клубово-стегнового сегменту // Шпитальна хірургія. - 2006. - № 1. - С. 36-40.

7. Венгер I. К. Системна запальна відповідь у розвитку реперфузійного синдрому при реконструкції атеосклеротичного ураження аорто-стегно-підколінного сегмента / I. К. Венгер, О. А. Якимчук, С. Я. Костів, А. С. Адарбех // Вісник Вінницького національного медичного університету. - 2010. - № 1. - C. 87-88.

8. Basic control of reperfusion effectively protects against reperfusion injury in a realistic rodent model of acute limb ischemia / F. Dick, J. Li, V. N. Girarud [et al.] // Circulation. 2008. - Vol. 118 (19). - P. 1920-1928. 


\section{REFERENCES}

1. Moller, E.R., \& Djaff, M.R. (2010). Zabolevanie perifericheskikh arteriy [Diseases of peripheral arteries]. Moscow: GEOTAR-Media [in Russian].

2. Belov, U.V., \& Stepanenko, A.B., (2009). Povtornye rekonstruktivnye operatsii na aorte i magistralnikh arteriyakh [Repeated reconstructive surgery on the aorta and main arteries]. Moscow: MIA [in Russian].

3. Nikulnikov, P.I., Bitsay, A.V., Ratushnyuk, A.V., \& Liksunov, A.V. (2013). Osobennosti khururgicheskoy taktiki pri mnogourovnevikh okkluzionno-stenoticheskikh porazheniyakh bedrenno-bertsovogo arterialnikh segmentov [Features of surgical tactics in multilevel occlusive-stenotic lesions of the femoral-tibial arterial segments]. Kharkivska khirurhichna shkola - Kharkiv Surgical School, 3, 148-151 [in Russian].

4. Marshalov, D.V., Petrenko, P.V., \& Glushach, I.A. (2008). Reperfussionnyy sindrom - ponyatie, opredilenie, klassifikatsiya [Reperfusion syndrome - concept, education, classification]. Patologiya krovoobrashcheniye i kardiokhirurgiya - Pathology of Blood Circulation and Cardiosurgery, 3, 67-72 [in Russian].

5. Dick F., Li J., Girarud V.N., Kalka C., Schmidli J., \& Tevaearai H. (2008). Basic control of reperfusion effectively protects against reperfusion injury in a realistic rodent model of acute limb ischemia. Circulation. 118 (19), 1920-1928.

6. Kostiv, S.Ya. (2006). Korektsiya reperfusiinoho syndromu pry khirurhicnomu likuvanni patsiyentiv iz aterosklerotuchnoiu okliuziieiu aorto-klubovo-stehnovoho sehmentu [Correction of reperfusion syndrome in cases of chronic obstructive pulmonary disease atherosclerotic occlusion of the aorto-ilio-femoral segment]. Shpytalna khirurhiia - Hospital Surgery, 1, 36-40 [in Ukrainian]. 7. Venher, I.K., Yakymchuk, O.A., Kostiv, S.Ya., \& Adarbech, A.S. (2010). Systemna zapalna vidpovid u rozvutku reperfusiinoho syndromu pry rekonstruktsii aterosklerotychnoho urazhennia aorto-stehno-pidkolinnoho sehmentu [The system inflamation responce in development of reperfusion syndrome at reconstruction of the atherosclerotic ulceration of the aortoilio-femoral segment]. Visnyk Vinnytskoho natsionalnoho medychnoho universutetu - Bulletin of the Vinnytsia National Medical University, 1, 87-88 [in Ukrainian].

8. Dick, F., Li, J., Girarud, V.N., Kalka, C., Schmidli, J., \& Tevaearai, H. (2008). Basic control of reperfusion effectively protects against reperfusion injury in a realistic rodent model of acute limb ischemia. Circulation, 118 (19), 1920-1928.

Отримано 08.05.2018

I. Horbachevsky Ternopil State Medical University ${ }^{1}$

Bukovinian State Medical University ${ }^{2}$

\section{PATHOPHYSIOLOGICALLY SUBSTANTIATED PROPHYLAXIS AND TREATMENT OF REPERFUSION-REOXYGENATIVE SYNDROME AT REVASCULARIZATION OF THE LOWER EXTREMITIES IN CONDITIONS OF CHRONIC CRITICAL ISCHEMIA}

\footnotetext{
The aim of the work: to improve the results of reconstructive operations on the aorta and major arteries under conditions of chronic critical ischemia of the lower extremities.

Materials and Methods. The work includes 56 patients with obliterating lesions of the aorta and arteries of the lower extremities of II, IIIA, IIIB, IV stages chronic arterial insufficiency.

For the prevention and treatment of the phenomena of no-reflow and reflow-paradox in the pre-operative period, a complex of proposed measures was implemented.

To diagnose the nature of the lesion of the arterial bed and the features of hemodynamic disturbances, indicators of ultrasound dopplerography, duplex scanning, X-ray contrast digital angiography were used. To obtain information on changes in capillary blood flow and arteriovenular blood flow, the method of laser doppler fluorometry was used.

Results and Discussion. By volume of revascularization patients are divided into two groups. Operative intervention in the 1st group of patients included single-stage aorto-bifermal bypass (14 observations) and one-sided aorto(ileo)-femoral bypass (8 observations). The second group included 34 patients who in addition to atherosclerotic occlusion aorto/ilia-femoral segment revealed stenotic-occlusive process femoral-popliteal segment. Dynamic ultrasound monitoring of hemodynamic femoral-popliteal segment postoperative patients II gr. revealed a decrease in peak systolic velocity and resistive index, which was an additional indication for reconstruction of the femoral-popliteal segment.
}

Key words: applying atherosclerosis; reperfusion-reoxygenative syndrome; revascularisation. 


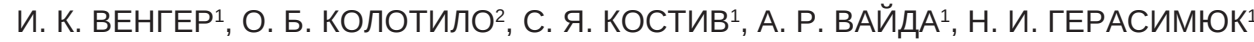

ГВУз “Тернопольский государственный медицинский университет имени И. Я. Горбачевского Мз Украины”"

ВГУЗ “Буковинский государственный медицинский университет МЗ Украины”2

\title{
ПРОФИЛАКТИКА И ЛЕЧЕНИЕ РЕПЕРФУЗИОННОГО ПОВРЕЖДЕНИЯ ТКАНЕЙ ПРИ РЕКОНСТРУКЦИИ АРТЕРИАЛЬНОГО РУС.ЛА АОРТО-БЕДРО-ПОДКОЛЕННОГО СЕГМЕНТА В УС.ЛОВИЯХ ХРОНИЧЕСКОЙ КРИТИЧЕСКОЙ ИНЕМИИ
}

Цель работы: улучшить результаты реконструктивных операций на аорте и магистральных артериях в условиях хронической критической ишемии нижних конечностей.

Материалы и методы. В работу включены 56 пациентов с облитерирующими поражениями аорты и артерий нижних конечностей с II, IIIA, IIIB, IV ст. хронической артериальной недостаточности.

Для профилактики и лечения феноменов no-reflow и reflow-paradox на дооперационном периоде осуществляли комплекс предложенных мероприятий.

Для диагностики характера поражения артериального русла и особенностей гемодинамических нарушений применяли показатели ультразвуковой допплерографии, дуплексного сканирования, рентгеноконтрастной цифровой ангиографии. Для получения информации об изменениях капиллярного кровотока и артерио-венулярного шунтирования крови применяли метод лазерной допплеровской флоурометрии.

Результаты исследований и их обсуждение. По объему реваскуляризации аорто/подвздошно-бедро-подколенного сегмента пациенты разделены на две группы. Оперативное вмешательство в первой группе пациентов включало одномоментное аортобифеморальное алошунтирование (14 случаев) и одностороннее аорто/подвздошно-бедренное алошунтирование (8 случаев). Во вторую группу включены 34 пациента, у которых, кроме атеросклеротической окклюзии аорто/подвздошно-бедренного сегмента, обнаружено стенотически-окклюзионный процесс бедро-подколенного сегмента. Динамический ультразвуковой мониторинг состояния гемодинамики бедро-подколенного сегмента в послеоперационном периоде у больных второй групы позволил выявить снижение пиковой систолической скорости и индекса резистентности, что было показанием к проведению дополнительной реконструкции бедро-подколенного сегмента.

Ключевые слова: облитерирующий атеросклероз; реперфузионно-реоксигенационный синдром; реваскуляризация. 